
Anca MITRACHE

Ipostaze sustenabile ale arhitecturii

Sustainable interfaces of architecture

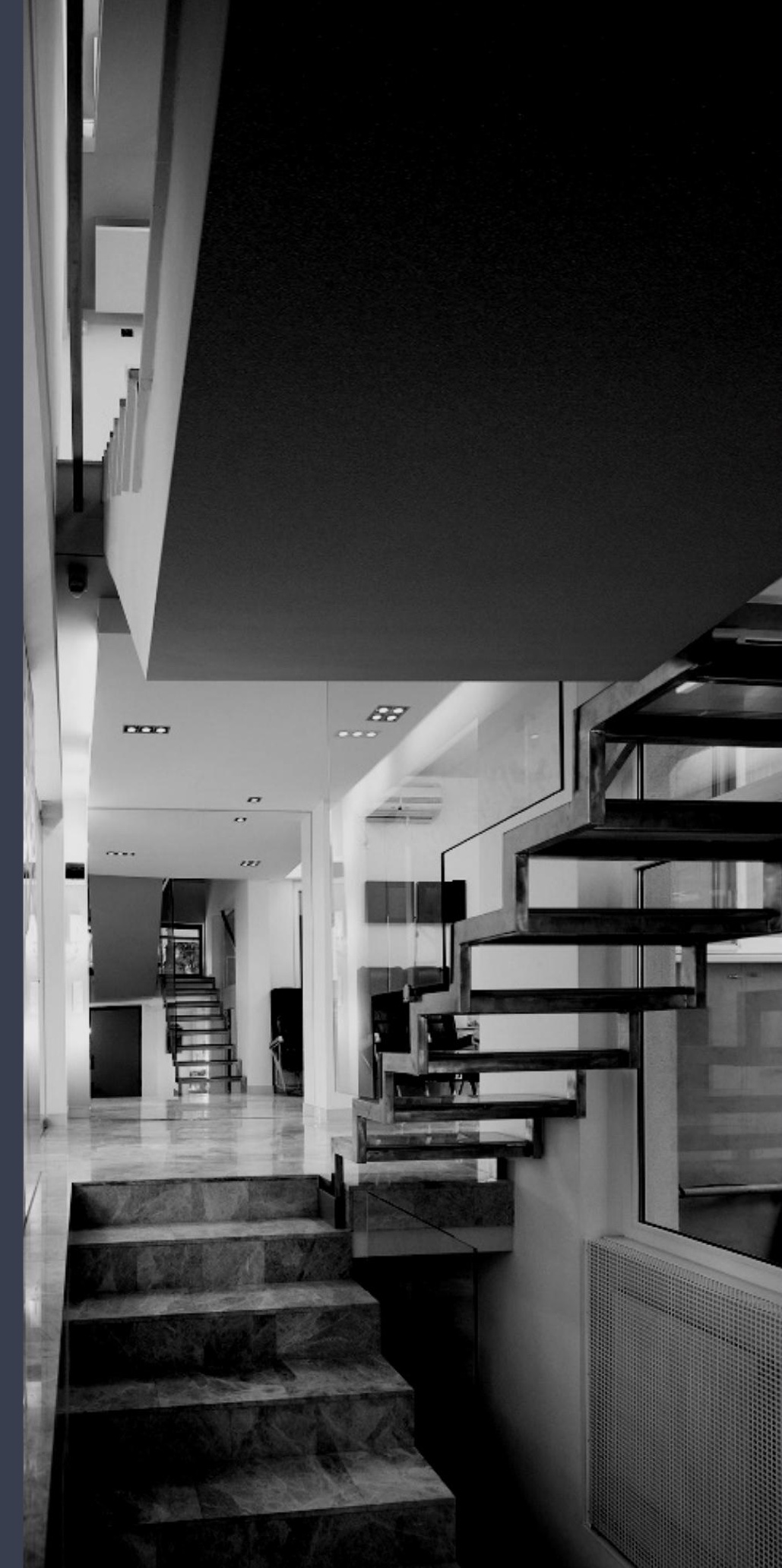




\section{Ipostaze sustenabile ale arhitecturii}

\section{Sustainable interfaces of architecture}

\section{Anca MITRACHE}

mitracheus.anca@gmail.com

Prof. Dr.Arhitect, SP*, FA UAUIM Prof. Dr.Architect, SP*, FA UAUIM

*Departament Sinteza Proiectării de Arhitectură Facultatea de Arhitectură Universitatea de Arhitectură și Urbanism lon Mincu UAUIM București *Synthesis of Architectural Design Department (SP)
Faculty of Architecture Ion Mincu University of Architecture and Urbanism UAUIM Bucharest
Reconcilierea imperativelor tehnologice $\mathrm{cu}$ intențiile formalizării spațiale într-o cheie locală, precum și cu mediul în care cele două componente vor produce un efect, reprezintă una dintre problemele sensibile cu care se confruntă astăzi practica de arhitectură. Formularea unei relații optime între arhitectura contemporană și tehnologiile bio-compatibile poate conduce la direcții de investigare neașteptate în arhitectură - prin analiza posibilităților de evoluție pe de o parte și, pe de altă parte, a relației dintre funcțiune, tehnologie, cost, organizare spațială și expresie arhitecturală.

cuvinte cheie

arhitectură, sustenabilitate
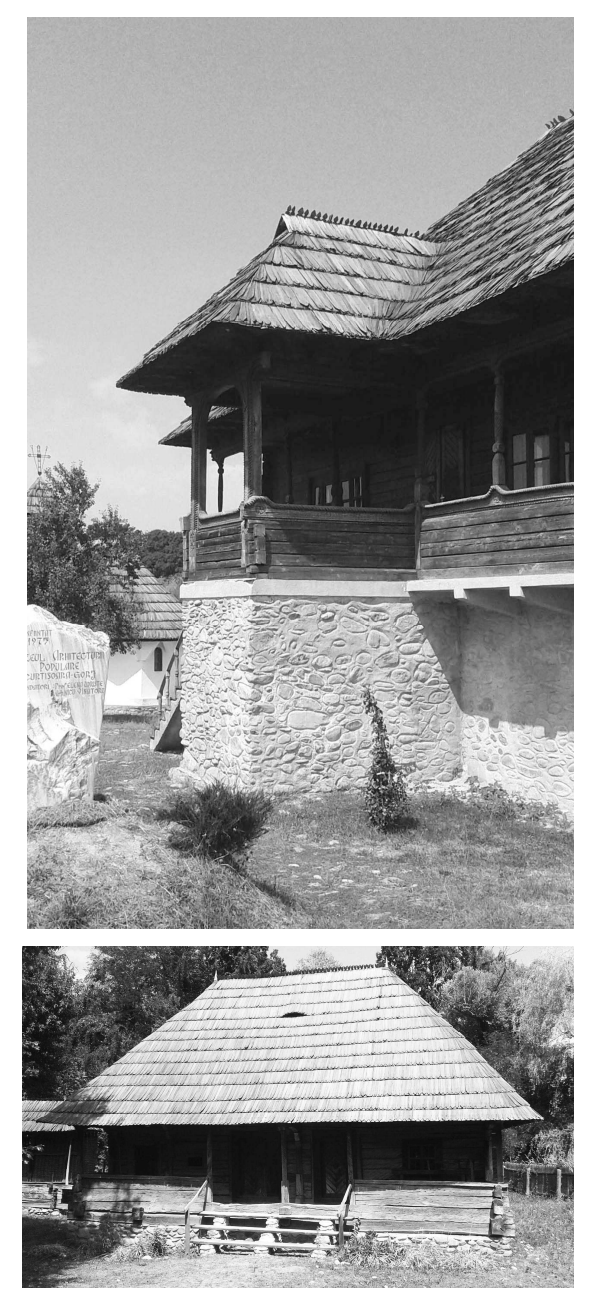
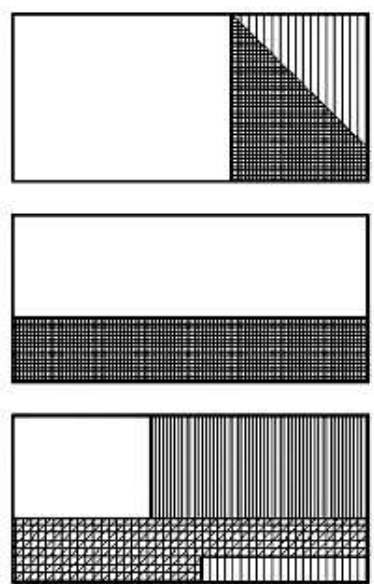

abstract

The reconciliation of technological imperatives with the intentions of spatial formalisation in a local key, as well as the environment in which the two components will create an impact, represents one of the imperative problems which face the practice of architectural design today. By achieving the ideal, balanced relationship between contemporary architecture and bio-compatible technologies we can open unexpected new paths of research in architecture - through the investigation of the opportunities of evolution on the one hand, and through the connection between function, technology, cost, spatial structure and architectural expression on the other. keywords

architecture, sustainability 


\section{INTRODUCERE}

Reconcilierea imperativelor tehnologice cu intențiile formalizării spațiale într-o cheie locală, precum și cu mediul în care cele două componente vor produce un efect, reprezintă una dintre problemele sensibile cu care se confruntă astăzi practica de arhitectură. Formularea unei relații optime între arhitectura contemporană și tehnologiile bio-compatibile poate conduce la direcții de investigare neașteptate în arhitectură - prin analiza posibilităților de evoluție pe de o parte și, pe de altă parte, a relației dintre funcțiune, tehnologie, cost, organizare spațială și expresie arhitecturală. (Fig.1)

Din punct de vedere estetic, procesul proiectării parcurge variante, experimente, cercetări și analize pentru a reprezenta un spațiu arhitectural ce exprimă o anume intenție. Elementele relevante în cheie sustenabilă ale arhitecturii actuale definesc fie elemente de limbaj formal, fie o anumită sintaxă legată de spațiu, fie ambele. Analiza prezentată în continuare include studii de caz, studii referitoare la elemente formale, inovații, propuneri compoziționale, și variante de materialitate. Subiectele mentionate au fost dezvoltate si îmbogățite prin experiment și cercetare. Studiul ar urma să se desfăşoare trecând în revistă exemplele de referință ale arhitecturii locale, elemente ce au generat de-a lungul timpului o tipologie spațială specifică în arhitectură, printr-un anumit tip de răspuns construit pentru $\circ$ anume necesitate. Perspectiva spațiului proiectat vizează un anumit tip de relație a obiectului de arhitectură cu contextul funcție de mesajul țintit - cultural, istoric, social, ambiental, functional etc. Elementele sale constitutive ar trebui să se situeze într-o relație sinergică ce definește simbolic compoziția de ansamblu prin proporții, prin imagine și/sau formă. (Fig.2)
În cadrul direcțiilor arhitecturale, aspecte privind protecția consumului de energie subliniază o serie de principii de dezvoltare durabilă a mediului construit care, prin teorie, metodă și practică de proiectare, pot și trebuie să răspundă unei abordări etice. Acest lucru oglindește un mod de reflexie asupra unei posibile transformări a arhitecturii, a teritoriului și a orașului. Termeni precum "economia verde", "orașe inteligente", "tehnologii emergente" au fost lansați pentru a clarifica diferitele poziționări și modificări ce pot contribui la reechilibrarea societății actuale.

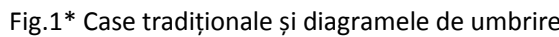
aferente / Traditional houses. Shadow diagrams (pagina anterioară / previous page)

Fig.2* Schemă de principiu a abordării etice/estetice în proiectare / General diagram of the ethical / aesthetic approach in design

*Imagini pentru publicare trimise de autorul articolului, Mitrache A. / Images for publication sent by the article's author, Mitrache A.

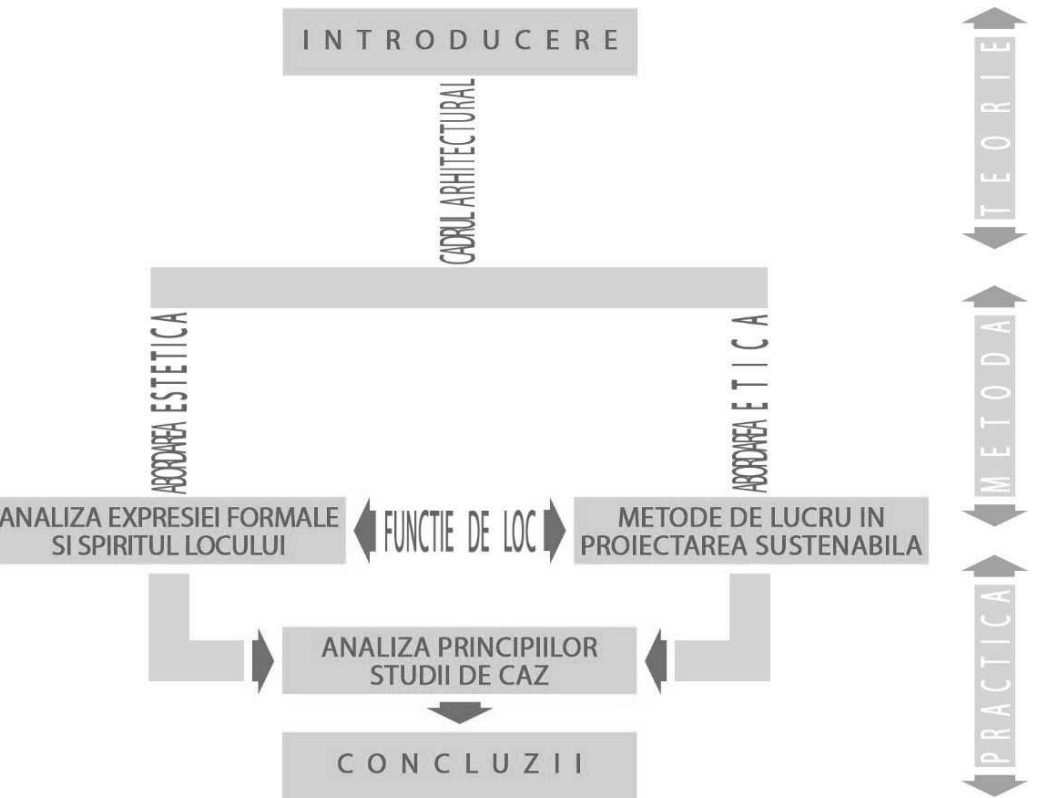




\section{CONSUM DE ENERGIE PENTRU UZ CASNIC}

\section{Aparate frigorifice $3 \%$}

\section{Electronice de consum 3\%}

Aparate pentru gătit $3 \%$

lluminat $3 \%$

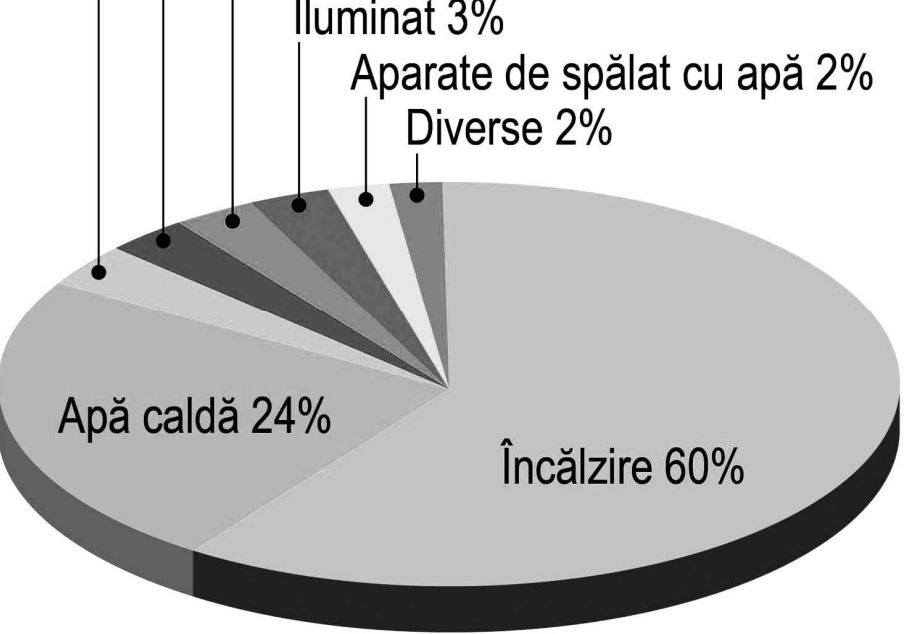

ABORDARE ETICĂ - DESIGN SUSTENABIL

Procesul de proiectare a unei clădiri reprezintă lucrul în echipă, o colaborare între arhitecți, ingineri de structură, ingineri de instalații, economiști, geologi, topografi, experți tehnologi și, desigur, auditori energetici. Echipa investighează aspecte ale mediului natural și construit în care va fi integrată noua clădire și calculează impactul viitoarei construcții. Procesul de proiectare, evoluează de la concept spre o anumită compoziție volumetrică, trebuie să țină cont de toți acești factori, rezultând o abordare sistemică. În final, clădirea reprezintă un mecanism: părțile constructive ale clădirii, care funcţionează împreună, si care dezvoltă un anumit comportament din punctul de vedere al consumului de energie, ce trebuie prognozat și prevăzut prin proiect. Arhitecții acordă atenție coerenței de percepere a spațiului prin compoziția volumetrică de ansamblu, dar în egală masură ei trebuie să includă în conceptul inițial și "anvelopa" clădirii - (element cu comportament termic), precum și configurația și poziția dispozitivelor de control a ventilării (încălzirii / răcirii aerului interior, sistemelor electrice si automatizate de control ambiental) interioare etc. (Fig.3)

\section{ABORDARE ETICĂ - PRINCIPII PASIVE}

În procesul de proiectare, unul dintre primii pași ce trebuie luați în considerare este utilizarea principiilor DESIGNULUI PASIV:- condițiile de amplasare;- poziția pe teren a volumului în funcție de orientarea față de punctele cardinale;- accesibilitatea, conectivitatea;structura și conformarea generală;- utilizarea materialelor. Exemplele care urmează vor ilustra utilizarea câtorva dintre principiile conformării arhitecturale:- bună iluminare și orientare cardinală;- bună ventilare a clădirii (generând convecția aerului prin conformarea volumetrică);utilizarea de dispozitive simple pentru economia energiei termice;- bună izolare termică a anvelopei.

(Fig.4)

Echilibrul dintre expresia structurală, materialitate ș formă, detaliu și, cel mai important, lumină (ca element unificator al compoziției spațiale și volumetrice) constituie un element-cheie în exprimarea intenției arhitecturale. Asigurarea luminii naturale precum și a celorlalte elemente ale percepției spațiale potențează capacitatea expresivă a arhitecturii și, împreună cu modalitățile de exprimare derivate din artă, pot crea tipuri noi de abordare expresivă specifică arhitecturii și pot îmbogăți semnificația pe care aceasta o poate evoca. (Fig.5)

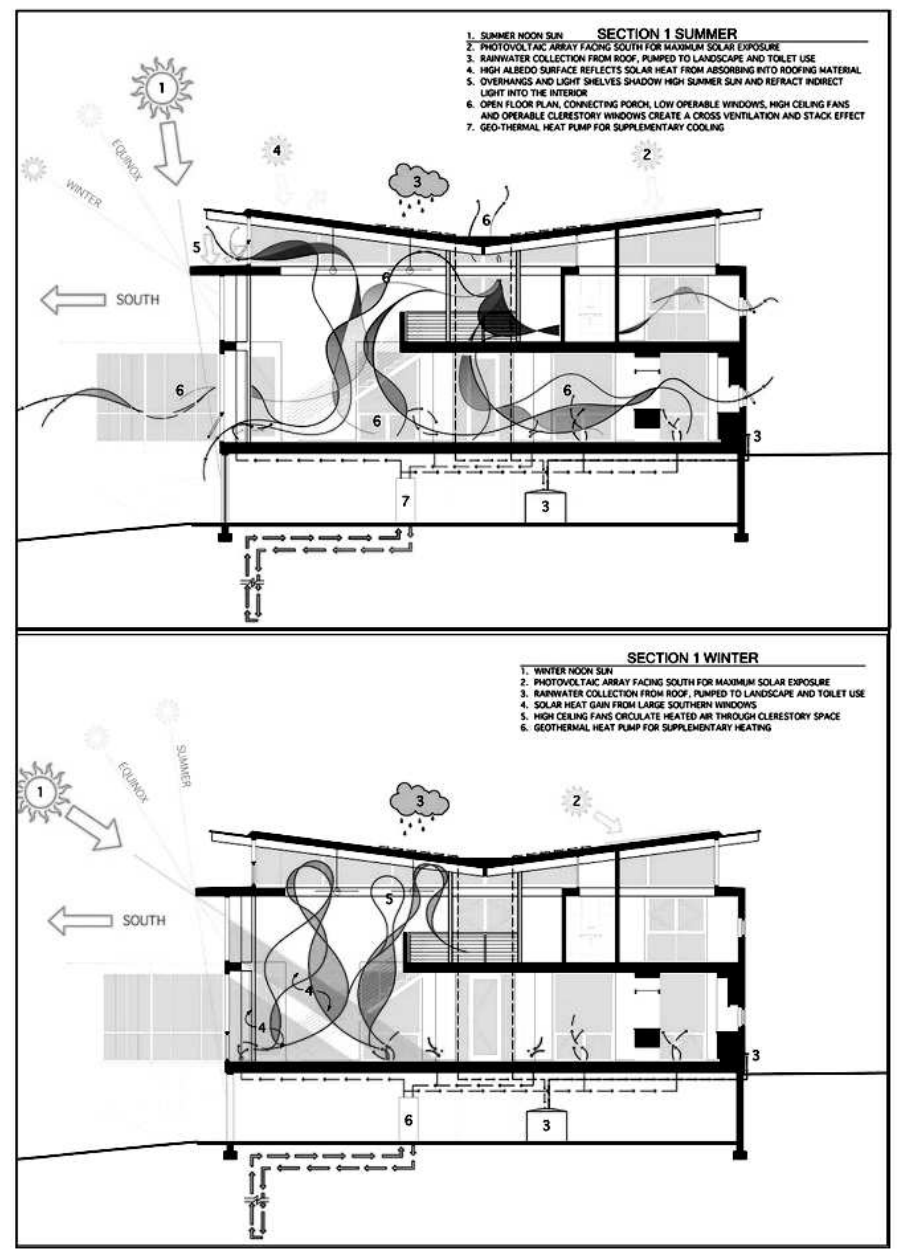


(pagina stângă / left page)

Fig.3* - Consumul de energie pentru uz casnic / Energy consumption for household use

Fig.4 Schema a comportării termice a climatului interior al unei locuinte sustenabile / Diagram of the thermal behaviour of the indoor climate of a sustainable home

\section{(pagina curentă / current page)}

Fig.5* Schema comportării termice și a dispozitivelor de control a circulației aerului interior - locuință str. V. Gherghel / Diagram of the thermal behaviour and of control devices for air circulation

Fig.6* - Schema comportării termice și a dispozitivelor de control a circulației aerului interior - locuință str. Șoimăreștilor / Diagram of the thermal behaviour and of control devices for air circulation, house on Soimarestilor Str.

*Imagini pentru publicare trimise de autorul articolului, Mitrache A. / Images for publication sent by the article's author, Mitrache A.

\section{ABORDARE ETICĂ - VENTILAṬIA NATURALĂ îN CLĂDIRE}

În acest exemplu pereții și terasa au fost izolate cu un strat de polistiren expandat de $10 \mathrm{~cm}$ grosime. Legislația construcțiilor din România prevede că pereții trebuie izolați cu cel puțin $10 \mathrm{~cm}$, iar grosimea minimă a izolației termice pentru terase ar trebui să fie de $15 \mathrm{~cm}$. Studiile de specialitate privind consumul de energie în clădiri evidențiază, de asemenea, necesitatea de a majora grosimea straturilor de izolare termică pentru terase (de la 12 la $15 \mathrm{~cm}$ ); subsolul ar trebui să fie izolat spre exterior cu cel puțin $8 \mathrm{~cm}$. (Fig.6)

Una dintre prioritățile proiectării este asigurarea calități aerului interior. În cazul clădirilor sustenabile, sistemul de recuperare a căldurii din aer poate produce valori nelf cu HR $\leq 75 \%$. Pentru a asigura un nivel convenabil al confortului interior, aerul curat ar trebui introdus în clădire la cel puțin $16,5^{\circ} \mathrm{C}$, fapt ce conduce la consumul unei energii pel $<=0,45 \mathrm{Wh} /$ $\mathrm{m}^{3}$. În plus, anvelopa clădirii trebuie să fie cât mai etanșă posibil $(<3 \%)$, cu un zgomot ambiental interior de maxim 25dB. (Fig.7)

Ferestrele trebuie să aibă o valoare a coeficientului de transmisie $\mathrm{U}$ nu mai mare de $0,8 \mathrm{~W} /\left(\mathrm{m}^{2} \mathrm{~K}\right)$, cu o valoare de transmitere a radiației termice $(\mathrm{g})$ de $50 \%$. Una dintre cele mai bune soluții este fereastra triplex, deși această alcătuire este mai costisitoare. Geamurile cu sticlă dublă au un coeficient de transmisie de 0,5 W/ $\left(\mathrm{m}^{2} \mathrm{~K}\right)$, iar sistemul se află întro evoluție continuă: ferestrele cu patru straturi de sticlă (și vid între geamuri) permit valori mai mici de $0,3 \mathrm{~W} /\left(\mathrm{m}^{2} \mathrm{~K}\right)$. Mai mult decât atât, în combinație cu filmele disponibile în diverse culori, acest tip de geam poate fi folosit ca și componentă estetică în proiectarea fațadelor. (Fig.8)

O anvelopă etanșă ajută la îmbunătățirea performanței în zonele cheie ale clădirii, crește nivelul de protecție împotriva zgomotului și asigură confortul termic. Un test de vânt aplicat ușilor une clădiri sustenabile ar trebui să prezinte pierderi de aer care nu depășesc 0,6 din volumul clădirii pe oră la o presiune de 50 Pascali. Mai mult decât atât, eficiența unității de ventilare cu un convertor de căldură (responsabil pentru extragerea căldurii din aerul interior și refolosirea acestuia) se aplică numa clădirilor cu pierderi de aer reduse. În același timp, o modelare adecvată a volumetriei poate facilita circulația aerului interior. (Fig.9)
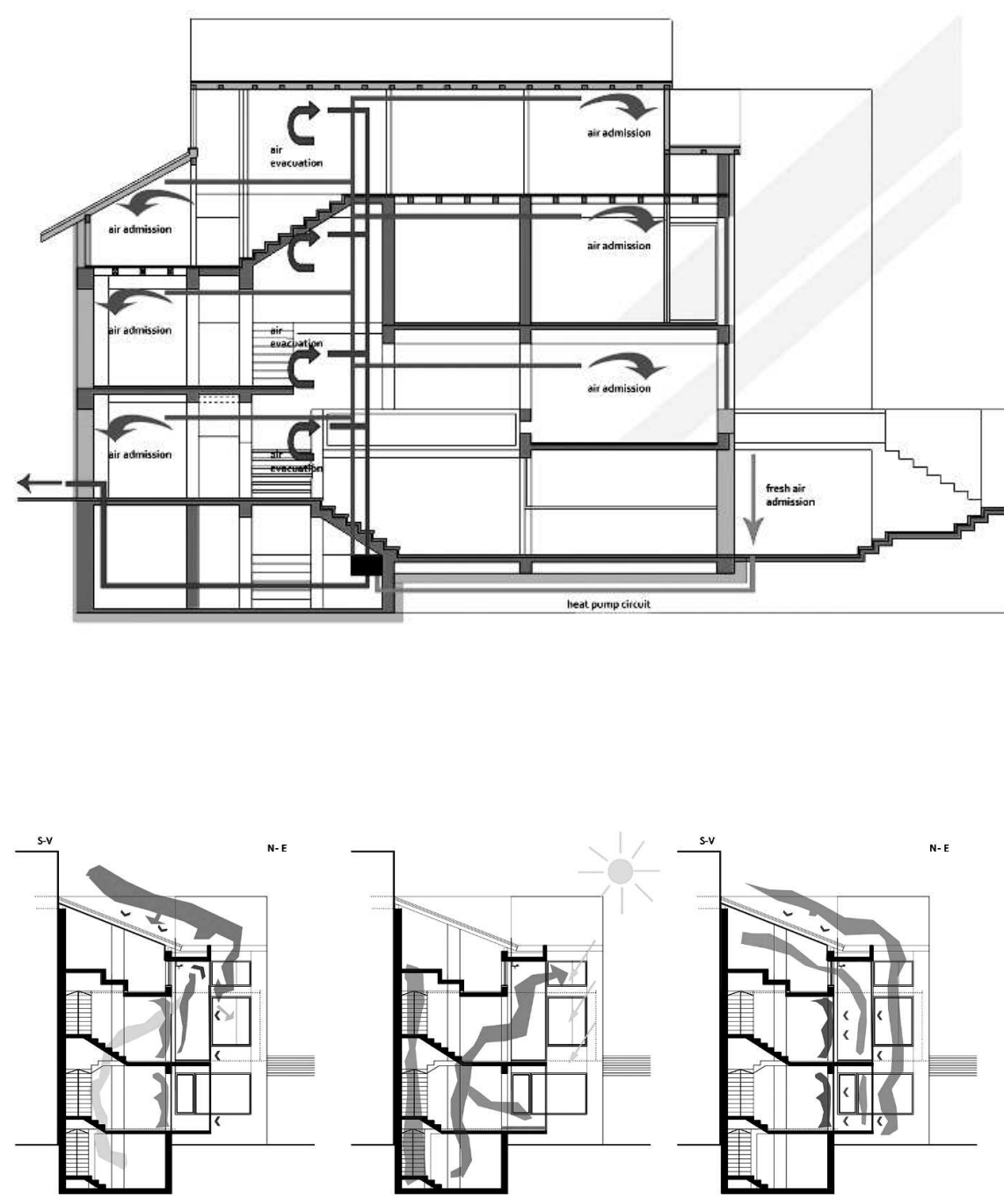

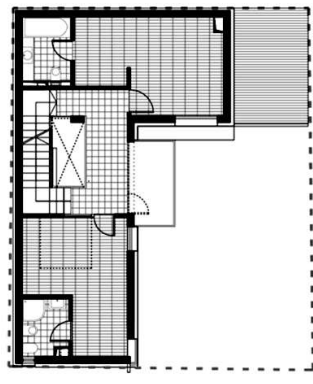

First Floor Plan

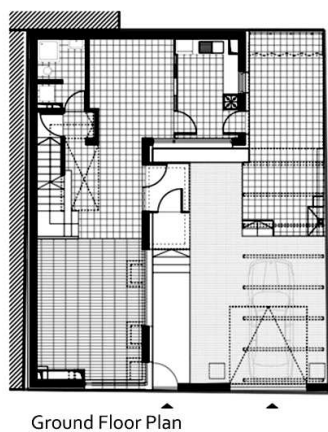


NATURAL VENTILATION INTHE BUILDING

WINTER
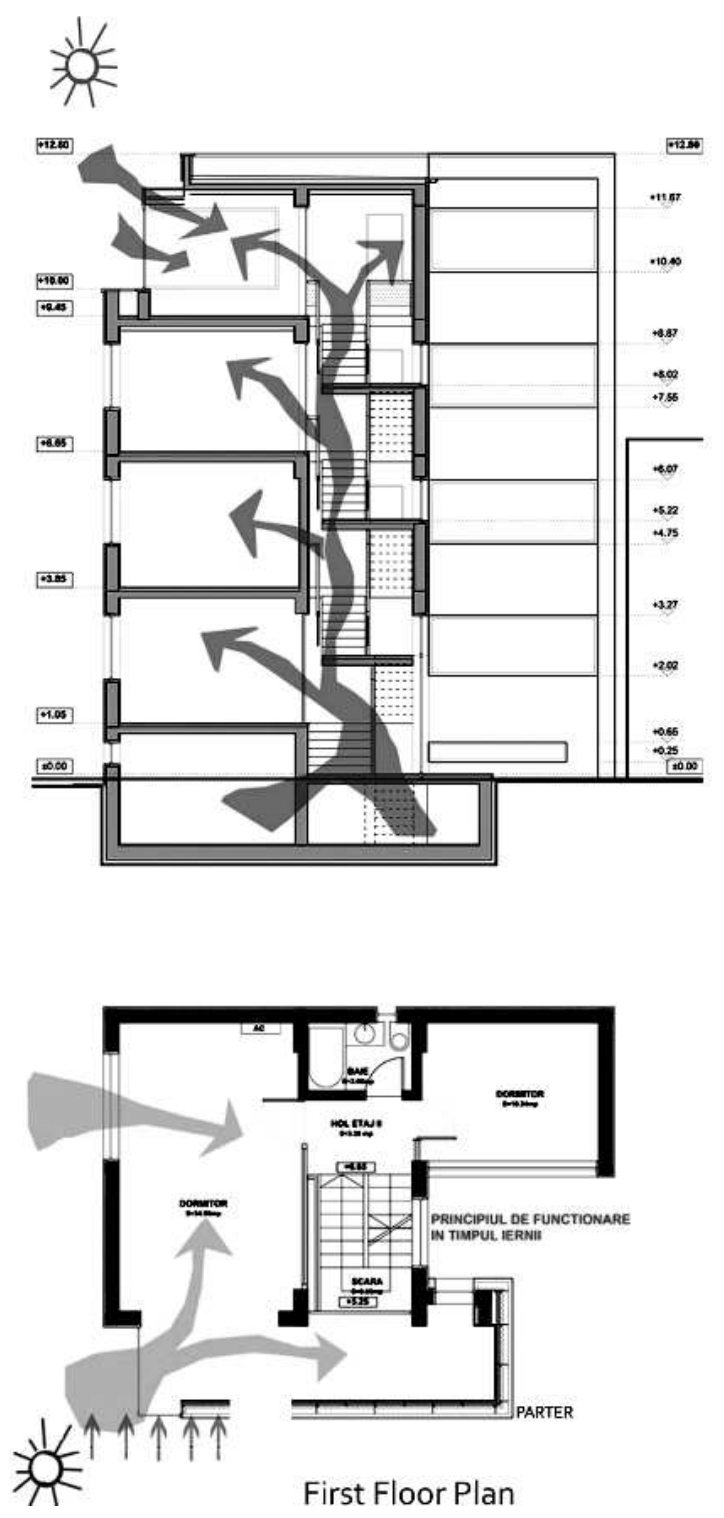

SUMMER
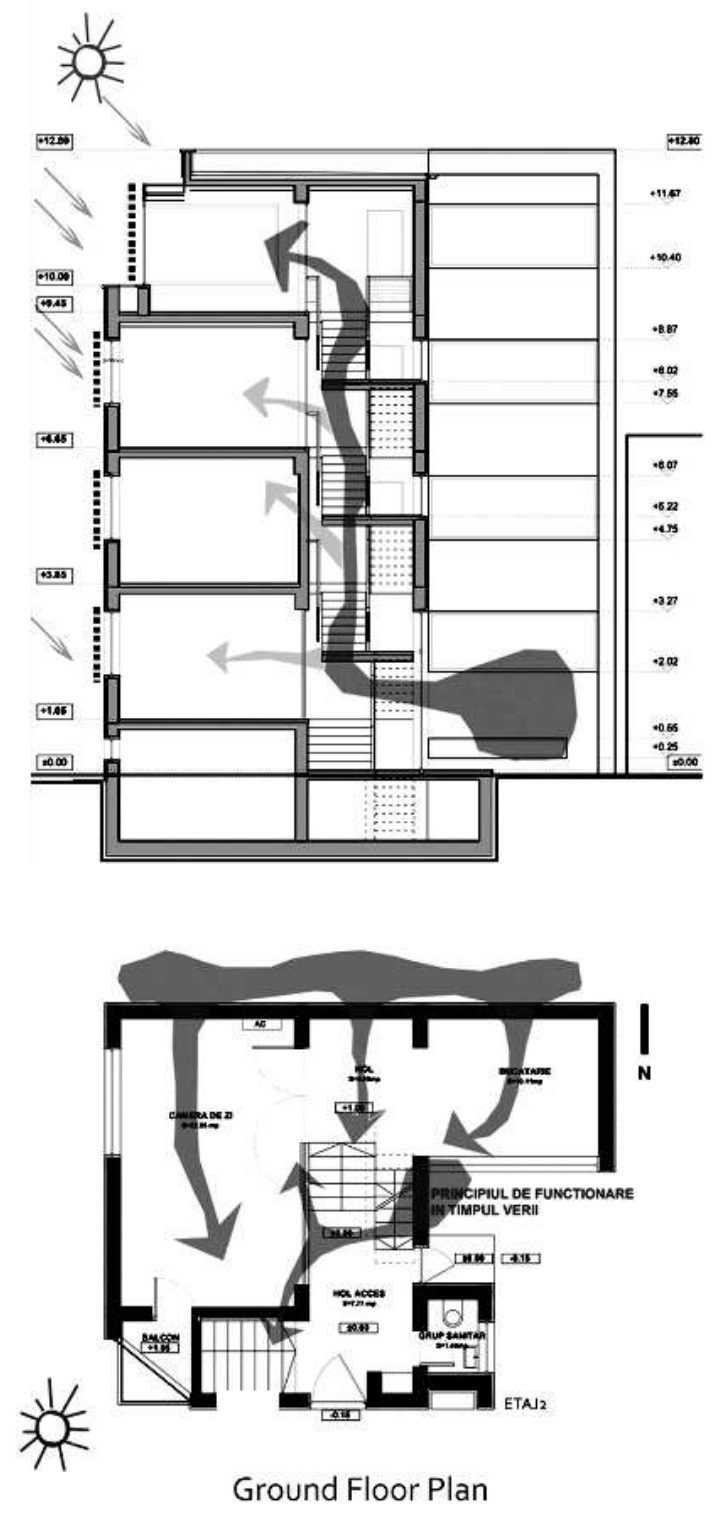

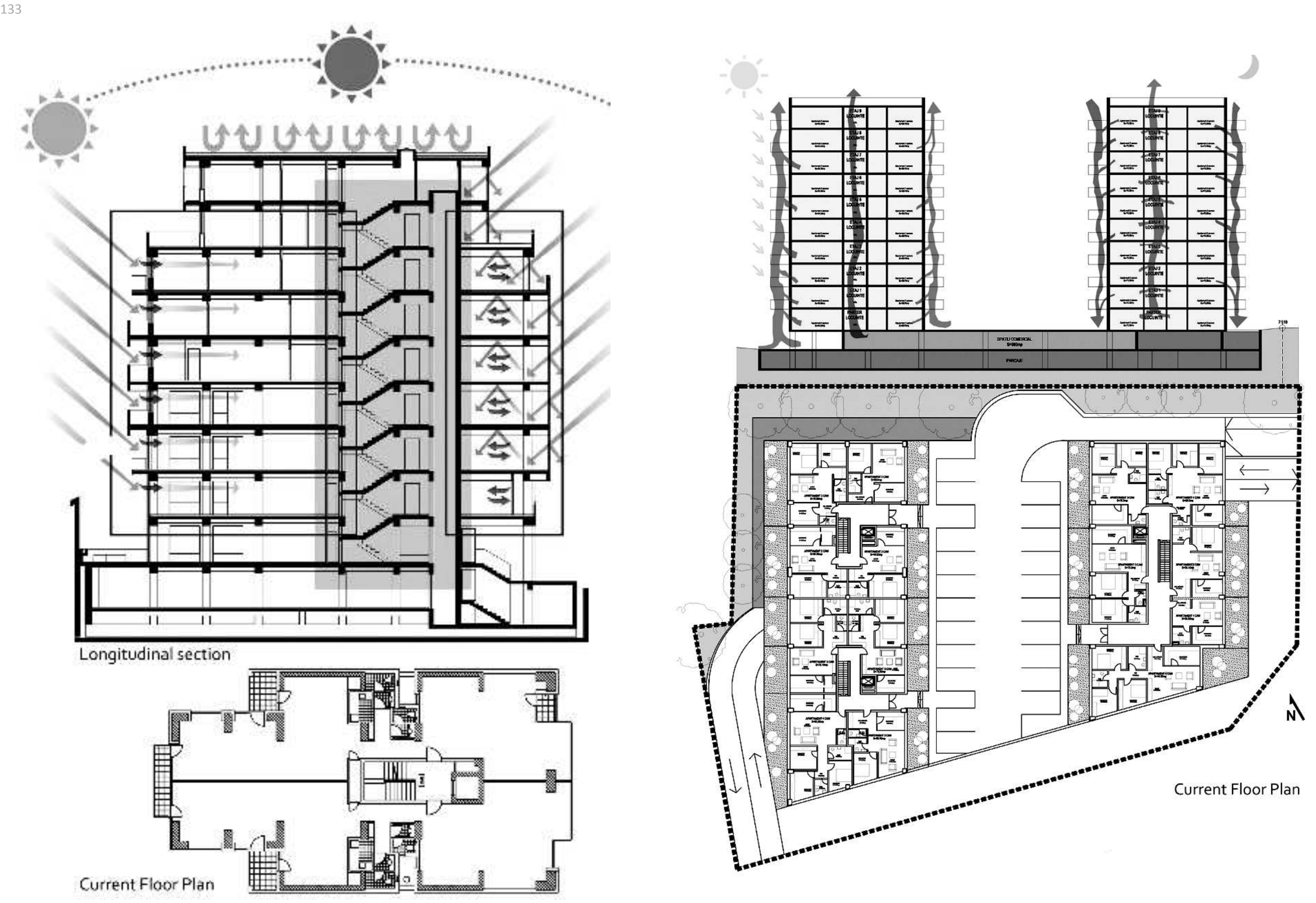

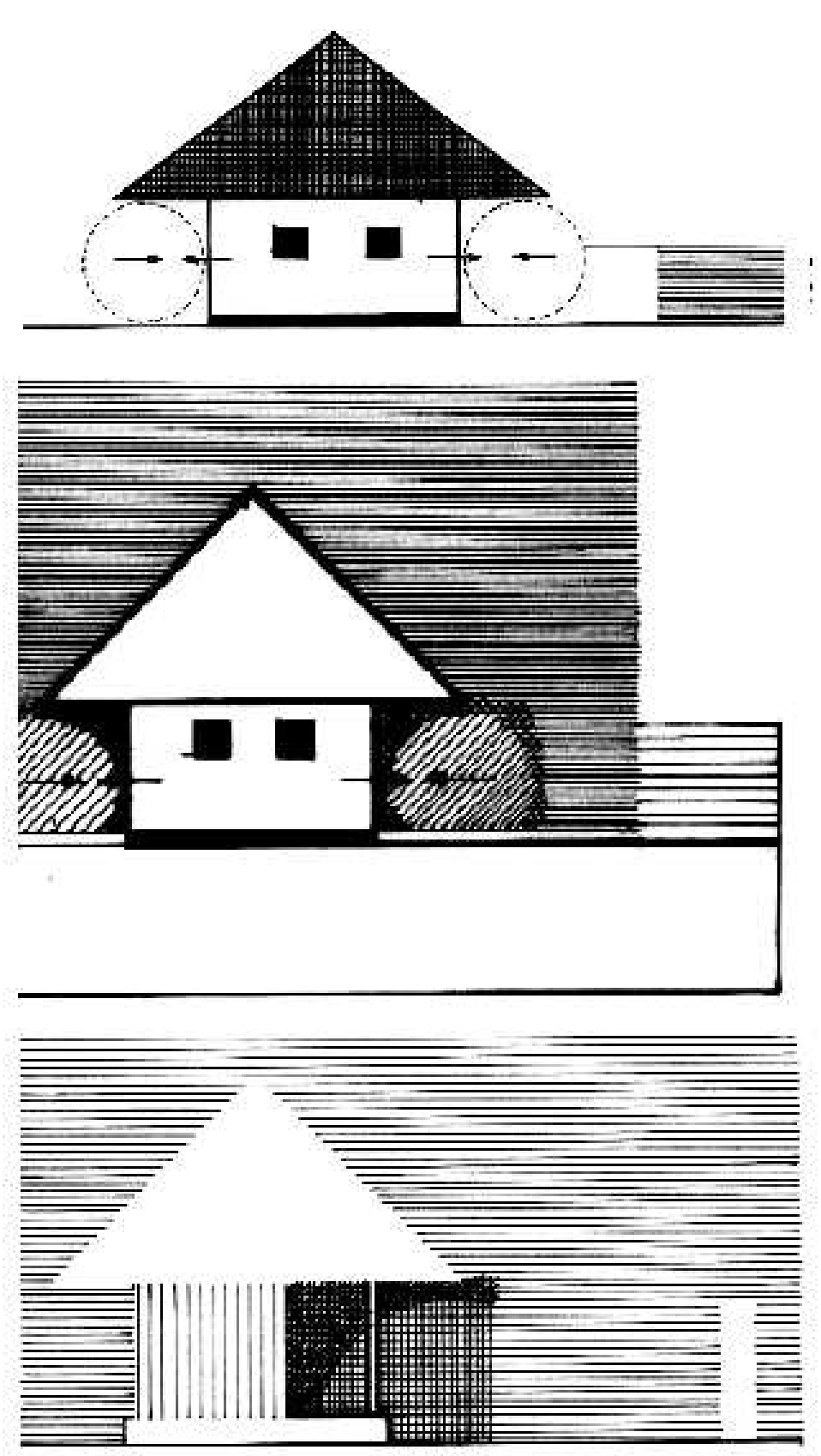

Diagrama spațiilor de influență ale volumelor principale
Fig.7* Schema comportării termice și a circulației aerului în clădire - locuință str. Sutașului / Diagram of the thermal behaviour and air circulation, house on Sutasului Str.

Fig.8* Schema comportării termice și a circulației naturale a aerului în clădire Imobil str. Polonă / Diagram of the thermal behaviour and air circulation, house on Polona Str.

Fig.9* Schema comportării termice și a circulației naturale a aerului în clădire - Imobil str. Logofăt Tăutu / Diagram of the thermal behaviour and air circulation, building on Logofat Tautu Str.

Fig.10* Diagrame compoziționale ale arhitecturii tradiționale / Compositional diagram of traditional architecture

Fig.11* Diagrama spațiilor de influență a volumelor principale locuință / The diagram of spaces of influence of the main volumes

*Imagini pentru publicare trimise de autoru articolului, Mitrache A. / Images for publication sent by the article's author, Mitrache A.
ABORDARE ESTETICĂ - ATITUDINI ALE DESIGNULUI SUSTENABIL

- arhitectura contextuală din punct de vedere al elementelor de limbaj formal;- potențarea atributelor relevante ale contextului și reformularea calităților arhitecturale ale spațiului; proiectarea în relație cu specificul cultural și lucrul cu spațiile și elementele arhitecturale într-o manieră compozițională logică- arhitectură contextuală contrastantă proiectarea spațiilor în cheie internațională, globală.

Mecanisme ce merită luate în considerare: presiunea modernizării;- îmbunătățirea nivelului de trai;- noile cerințe de mediu.

Abordarea estetică printr-o atitudine sustenabilă implică cunoașterea elementelor de continuitate culturală privite din punct de vedere sustenabil și reperelor specifice ale sitului. Când spunem acest lucru, ne gândim nu numai la exemple tradiționale de arhitectură, ci și la manifestări arhitecturale moderne. Ambele reprezintă, în acest caz, "expresia spațială a spiritului local". (Fig.10)

\section{ABORDARE ESTETICĂ - SINTAXA SPATIIALĂ}

-teorii, metode și tehnici ale sintaxei spațiului; analiza conceptelor și sistemelor arhitecturale, determinarea rolului lor în crearea arhitecturi durabile, a unei societăți mai bune și a unui proces de proiectare informat; -aplicarea conceptelor teoretice și analitice la studiile de caz practice.

Abordarea ESTETICĂ face referire la elementele de identitate prin analiză și metode de lucru ce utilizează componentele și conceptele arhitecturale. Aceste aspecte conferă echilibru clădirii ca întreg. Proiectele prezentate în continuare urmăresc să puncteze două aspecte ale aceleiași probleme: 
arhitectura percepută atât ca gest etic, cât și ca gest estetic. (Fig.11)

\section{ÎN LOC DE CONCLUZIE}

Clima a influențat de-a lungul timpului caracterul arhitecturii. Exemplele studiate au înfățisat câteva dintre proiectele recente care au integrat principiile pasive ale arhitecturii durabile în zona noastră. Proiectarea ia în calcul câteva componente esențiale ce privesc Principiile Pasive de utilizare a energiei neconvenţionale:

-Context - analiza existentului, sinteza informațiilor relevante legate atât de functionarea viitoarei propuneri într-un tesut (urban) existent, cât și a elementelor legate de orientare față de punctele cardinale, circulația aerului în zona, natura terenului, a reliefului, caracteristici climatice locale, dar și accesibilitate și relaţionare cu vecinătatea, context socio-cultural etc.

-Concept - ca răspuns la problematica și oportunitățile furnizate de analiza contextului și a temei de proiectare.

-soluții optime privind eficientizarea consumului de energie a viitoarei propuneri

- conformare spatial-volumetrică - functiune versus caracteristici teren / amplasament

- conformare spațial-volumetrică - functiune versus orientări cardinale

- conformare spațial-volumetrică - funcțiune versus vânturi dominante / fenomene locale

- conformare spațial-volumetrică - funcțiune versus circulația naturala a aerului in clădire

- conformare spațial-volumetrică - funcțiune versus suprafete / spații luminate natural

-Structurare spaţială - răspunsul spațial-formal obținut reflectă soluția de structură și materialul ales în acord cu tema și cu raportul cel mai eficient privind costuri contra timp de execuție.
-Funcțiune - conceperea unei rezolvări funcționale mcoerente, complete și conforme cu strategia eficienței energetice pe ansamblu clădire

-Tehnologii - realizarea unui demers de concept si proiectare complet și coerent într-un sistem integra (arhitectură, urbanism, structură, instalații, peisagistică etc.)

Strategiile menționate anterior sunt utilizate alături de inovațiile tehnice, cerințele funcționale și o atentă detaliere pentru a propune clădiri cu comportament eficient al consumului de energie și care permit o gamă largă de expresii arhitecturale.

Reconcilierea imperativelor și oportunităților tehnologice $\mathrm{cu}$ preocupările umane mai ample precum si cu cele legate de mediul înconjurăto reprezintă, astăzi, una dintre cele mai provocatoare probleme cu care se confruntă arhitectura.

Sursa imaginilor / Source of images:

Fig.1 Grigore lonescu, Istoria arhitecturii în România, Vol. 1, Editura Academiei Române, 1963, București;

Georgică Mitrache, Tradiție și modenism în arhitectura românească, Editura Universitară Ion Mincu, 2008, București;

Fig.1 Grigore lonescu, The History of Architecture in România, Vol. 1. Romanian Academy Press, 1963, Bucharest

/ Georgică Mitrache, Tradition and modernism in romanian architecture, Ion Mincu University Press, 2008, Bucharest

Fig.2-9 Sursă proprie autor;

Fig.2-9 Author's sources;

Fig.10,11 Georgică Mitrache, Tradiție și modenism în arhitectura românească, Editura Universitară Ion Mincu, 2008, București.

Fig.10,11 Georgică Mitrache, Tradition and modernism in romanian archicecture, Ion Mincu University Press, 2008, Bucharest.
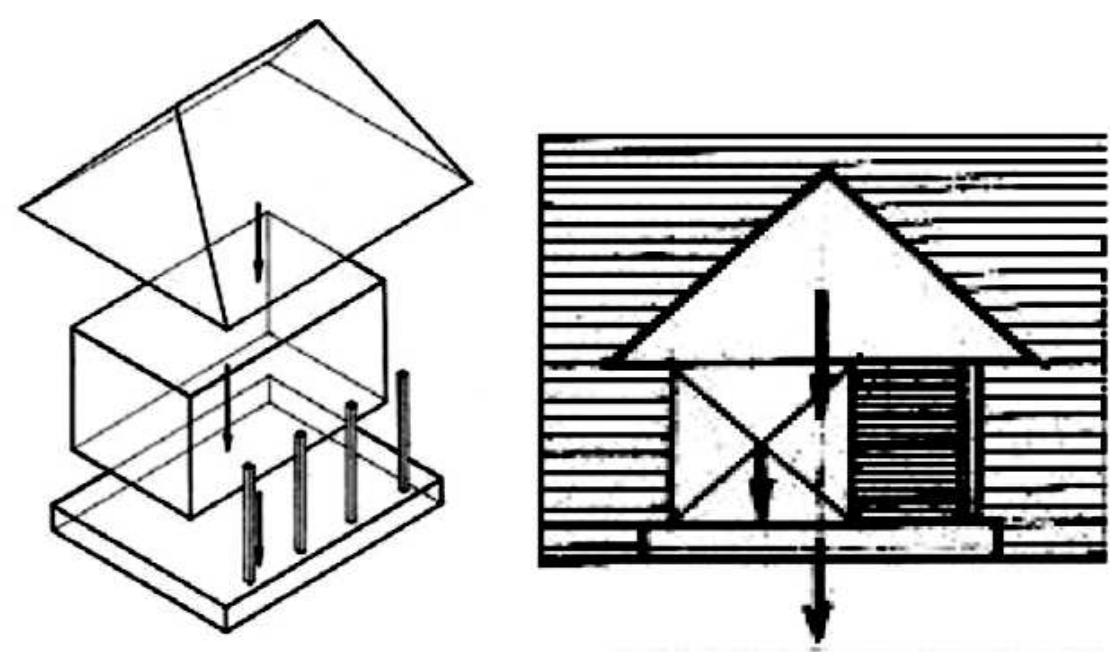
(english version)

\section{INTRODUCTION}

The reconciliation of technological imperatives with the intentions of spatial formalisation in a local key, as well as the environment in which the two components will create an impact, represents one of the imperative problems which face the practice of architectural design today. By achieving the ideal, balanced relationship between contemporary architecture and bio-compatible technologies we can open unexpected new paths of research in architecture - through the investigation of the opportunities of evolution on the one hand, and through the connection between function, technology, cost, spatial structure and architectural expression on the other. (Fig.1)

From an aesthetic point of view, the design process goes through experiments, research and analysis in order to achieve the representation of an architectural space which expresses a certain compositional intention. Relevant sustainable aspects in today's architecture define either elements of formal language, a certain syntax linked to the space, or both of the above.

The analysis includes case studies, research of formal and composition elements, materiality and innovations. These subjects were developed and enriched by experiment in architectural design and research.

The following study (Fig.2) aims to bring to attention valuable examples of local architecture, which with time have generated a specific typology of space as a certain built type of response to a certain type of necessity. The architectural space generates a particular type of connection between the built object and its context according to the message it intends to convey, whether it has a cultural historical, social, environmental, or functional nature.

Its constitutive elements should be in a tight connection which defines, at a symbolic level, through proportions, image and/or shape, the overall composition.

Architecture as profession is nowadays the subject of regulations concerning the consumption of energy and sustainable principles of development for the built environment which should reflect - through theory, methods and design - an ethical approach in an aesthetic manner. This approach involves a specific introspection regarding the possible ways of transformation in connection to architecture and urban territory. Concepts such as "green economy", "smart cities", "emerging technologies" have been defined in order to clarify the various positions and shifts which can contribute to the reevaluation of the present society - built environment relationship.

\section{ETHICAL APPROACH - SUSTAINABLE DESIGN}

The process of building design is a team effort - a collaboration between architects, structura engineers, systems engineers, economists, geologists, topographers, technology experts and, of course, energy auditors. This complex team has to investigate aspects of the existing natural and built environment into which the new building will be integrated, and to calculate the impact of the future construction. The design process, evolving from concept to a particular volumetric composition, has to take into account all of these factors, resulting in a systemic approach. In the end, the building itself is a system: the constructive parts of the building, working together, develop a certain behaviour from the point of view of the energy consumption, which should be anticipated and included in the project. 
The architects pay attention not only to the volumetric composition, but also show a keen interest in the building's "skin" - its envelope (a thermal active element) - and in the configuration and distribution of intelligent control systems of ventilation (air heating/cooling, automated electrical and environmental control systems). (Fig.3)

\section{ETHICAL APPROACH - PASSIVE PRINCIPLES}

In the process of architectural design, one of the initial steps to take into consideration is the use of PASSIVE DESIGN PRINCIPLES:

Principles regarding the analysis of the site of the future building:

- site conditions

- on-site position of the volume according to cardinal orientation

- accessibility, connectivity

- structure and overall compliance

- use of materials.

\section{(Fig.4)}

The following examples illustrate the use of some of the architectural compliance principles:

- good lighting and cardinal orientation

- good ventilation in the building (generating air convection through spatial volumetric conformation)

- use of simple devices to aid in the economy of indoor thermal energy

- good thermal insulation

The balance between structural expression, material and form, detail, and most importantly light as the unifying element of the spatial and volumetric composition can constitute key-elements in expressing architectural intention. The component of light and other elements of spatial perception increase the expressive capacity of architecture and, along with the ways of expression derived from art, can create new types of specific expressive approach to architecture and enrich the meaning that it could evoke. (Fig.5)

In the following example, the walls and terrace were insulated with a 10 centimeters thick layer of expanded polystyrene. Construction legislation in Romania stipulates that walls should be insulated with layers of at least $20 \mathrm{~cm}$, while the minimum thickness of thermal insulation for terraces should be $15 \mathrm{~cm}$. Expert studies in building energy also highlight the need to increase the thickness of the thermal insulation layers for terraces (from 12 to 15 $\mathrm{cm})$; the basement too should be insulated with an 8 $\mathrm{cm}$ exterior layer.

\section{ETHICAL APPROACH - NATURAL VENTILATION} INSIDE THE BUILDING

One of the main design priorities is the quality of interior air.

For sustainable buildings, the system of heat recovery from the air may produce values around nelf, $H R \leq 75 \%$. In order to guarantee a convenient level of interior comfort, fresh air must be introduced into the building with a temperature of at least $16.5^{\circ} \mathrm{C}$ through the consumption of an energy of pel $\leq 0.45 \mathrm{~W} \mathrm{~h} / \mathrm{m}^{3}$.

Furthermore, the building's envelope must be as tight as possible (<3\%), with a maximum of $25 d B$ for the ambiental noise (A). (Fig.6)

The value of the coefficient of transmission " $U$ " for windows should be lower than $0.8 \mathrm{~W} /\left(\mathrm{m}^{2} \mathrm{~K}\right)$, with a transmission of heat radiation $(\mathrm{g})$ of $50 \%$. One of the best solutions is the triplex window, although they tend to be pricier. Double glazed windows have a 0.5 $W /\left(m^{2} K\right)$ coefficient of transmission, and the system is rapidly evolving: windows with four layers of glass (with vacuum between the panes) allow for values of 
less than $0.3 \mathrm{~W} /\left(\mathrm{m}^{2} \mathrm{~K}\right)$. Moreover, in combination with cling films available in various colours, this type of glazing can be used as a façade design component. (Fig.7)

Envelope tightness helps improve performance in key areas of the building, it raises the level of protection against noise and ensures thermal comfort. A wind test applied to the doors of a sustainable building should show air losses no bigger than 0.6 of the building's volume per hour (n50 $\left.\leq 0.6 h \square{ }^{-1}\right)$ at a pressure of 50 Pascals. Moreover, the efficiency of the ventilation unit with a heat exchanger (responsible for drawing heat from the interior air and reusing it) applies only to buildings with reduced air losses. At the same time, an adequate shaping of the geometrical volume can facilitate interior air circulation. (Fig.8)

\section{AESTHETIC APPROACH - ATTITUDES SUSTAINABLE DESIGN}

- contextual architecture from the point of view of architectural elements;

- emphasis on contextually relevant attributes and the reiteration of the architectural qualities of space; the design process in relation to specific cultural elements and the use of elements of architectural expression in a logical compositional manner

- contrasting contextual architecture designing in a manner of expression which is internationally recognizable

Mechanism to be considered:

- the pressure of achieving present standards

- improvement of quality of life

- new environment requirements

A sustainable approach from an aesthetic point of view involves knowing the elements of cultural continuity (seen from a sustainable point of view) and the cultural landmarks specific to the site. When asserting this, we consider not only traditional examples of architecture, but also modern architectural manifestations. Beth represent, in this case, the "spatial expression of genius loci". (Fig.10)

\section{AESTHETIC APPROACH - SPATIAL SYNTAXIS}

- theories, methods, and expression techniques of spatial syntax;

- the analysis of concepts and architectural elements; assessing their role in the process of creating durable architecture; an adequate answer to the present society and a well-informed design process;

- using theoretical and analytical concepts in case studies.

The aesthetical approach uses architectural elements by means of analysis and working methods specific to the field of art. A good knowledge of concepts familiar to the process of creation and the transformation of artistic composition such as scale, proportion, rhythm, compositional balance represents the guarantee of a well calibrated building. From a cultural sustainability point of view the use of elements that are culturally and locally familiar as a supplement to the formal means of expression should lead to the development of a unique architectural object which is culturally as well as anthropically sustainable.

The following projects aim to emphasize two facets of the same problem: architecture perceived as an ethical gesture and architecture as an aesthetic object. (Fig.11)

\section{INSTEAD OF CONCLUSION}

Over time, climate has represented a powerful influence on the character of architecture. The examples presented above illustrate some of the more recent project which have integrated the 
passive principles of sustainable architecture in our region. Contemporary architecture takes into consideration a few essential components regarding Passive Principles of renewable energy consumption in the built environment:

- CONTEXT - the analysis of existing context, the synthesis of relevant information regarding the development of the proposed building in the existing urban fabric as well as aspects concerning cardinal orientation, air currents in the area, the nature of the topography, micro-climate characteristics, accessibility and relation to the vicinity, sociocultural context etc.

CONCEPT - as answer to the problems and opportunities resulted from the study of the context and of the project theme;

-adequate solutions regarding the efficiency of energy consumption in the proposed building:

- spatial-volumetric conformation - function vs plot characteristic

- spatial-volumetric conformation - function vs cardinal orientation

- spatial-volumetric conformation - function vs dominant winds/local phenomena

- spatial-volumetric conformation - function vs natural air circulation inside the building

- spatial-volumetric conformation - function vs surfaces/spaces with natural light

SPATIAL STRUCTURE - the formal-spatial answer reflects the chosen structural and tectonic solution according to the project brief and the most efficient proportion between cost and time of execution

-FUNCTION - the proposal of a coherent and complex functional solution, compatible with the strategy of energetic efficiency for the entire building.

-TECHNOLOGIES - the development of a complex and coherent approach for an integrative system of design (architecture, structure, installation, landscape etc)
The reconciliation of the imperatives and technological opportunities with the broader human concerns as well as those related to the environment, represents nowadays one of the most challenging problems facing architecture.

In order to offer, in nowadays practice, a concept of building with efficient energy consumption behaviour, it is necessary to include the strategy mentioned above in the design process. Together with the technical innovations and state of the art smart devices, these strategies can - in an appropriate functional scenario- offer the chance of a new architectural expression ready to be explored.

\section{Citare articol curent / Citation}

(Ro)

Mitrache A. (2021). Ipostaze sustenabile ale arhitecturii. în Teoria proiectului de arhitectură. Idei construite. SP FA UAUIM. EUIM - Editura Universitară Ion Mincu, București.

(En)

Mitrache A. (2021). Sustainable interfaces of architecture. in Architectural design theory. Built ideas. SP FA UAUIM. EUIM Ion Mincu University Publishing House, Bucharest. 


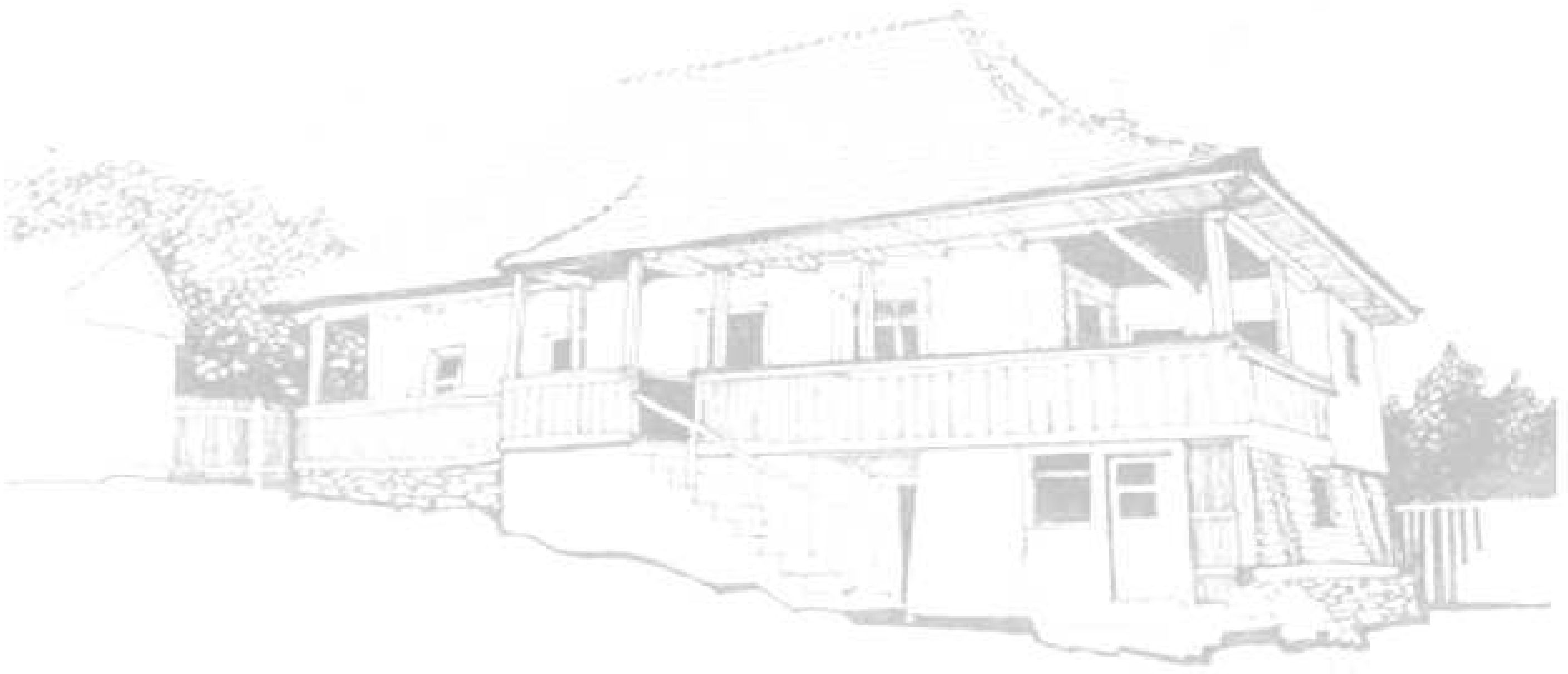


